\title{
THE TRAGIC MULATTA AND STORYTELLING IN ZORA NEALE HURSTON'S THEIR EYES WERE WATCHING GOD
}

\author{
Ana Belén Pérez García \\ Universidad Nacional de Educación a Distancia (UNED, Spain)
}

\begin{abstract}
The figure of the tragic mulatta placed its origin in antebellum literature and was extensively used in the literature of the nineteenth and twentieth century. Much has been written about this literary character in a time when the problem of miscegenation was at its highest point, and when studies established that races were inherently different, meaning that the black race was inferior to the white one. Many authors have made use of this trope for different purposes, and Zora Neale Hurston was one of them. In her novel Their Eyes Were Watching God, Hurston creates Janie, a mulatta that a priori follows all the characteristics of this type of female character who, however, breaks away from most of them. She overcomes all stereotypes and prejudices, those imposed on her because of her condition of interracial offspring, and is able to take charge of her own life and challenge all these impositions feeling closer to her blackness and celebrating and empowering her female identity. In this vein, storytelling becomes the liberating force that helps her do so. It will become the tool that will enable her to ignore the need of passing as a white person and provide her with the opportunity to connect with her real identity and so feel free and happy, breaking with the tragic destiny of mulatta characters.
\end{abstract}

Keywords: storytelling, tragic mulatta, blackness, Hurston.

\section{Resumen}

La figura de la mulata trágica tiene su origen en la literatura anterior a la guerra y se usó de manera extensa en la literatura de los siglos diecinueve y veinte. Se ha escrito mucho sobre este personaje literario, sobretodo en una época en la que el problema del mestizaje estaba en su punto más álgido, y en la que los estudios establecían que las razas eran inherentemente diferentes, entendiéndose que la raza negra era inferior a la blanca. Muchos autores han hecho uso de este tropo con diferentes propósitos, y Zora Neale Hurston fue una de ellos. En su novela Their Eyes Were Watching God, Hurston crea a Janie, una mulata que a priori tiene todas las características de este tipo de personaje femenino pero que, sin embargo, rompe con todos ellas. Supera todos los estereotipos y prejuicios 
impuestos sobre ella por su condición de descendiente de una relación interracial, y además es capaz de tomar las riendas de su vida y retar a todas estas imposiciones, sintiéndose cada vez más cerca de su raza y celebrando y empoderando su identidad femenina. En este sentido, la narración oral se convierte en la fuerza liberadora que la ayuda a conseguirlo. Se convertirá en el instrumento que la capacite para ignorar la necesidad de hacerse pasar por una persona blanca y le dará la oportunidad de conectar con su verdadera identidad y de sentirse libre y feliz, rompiendo con el destino trágico que espera a los personajes mulatos.

Palabras clave: narración oral, mulata trágica, negrura, Hurston.

The figure of the tragic mulatta placed its origin in antebellum literature and was extensively used in the literature of the nineteenth and twentieth century. Much has been written about this literary character in a time when the problem of miscegenation was at its highest point, and when studies established that races were inherently different, meaning that the black race was inferior to the white one. This meant that the offspring of interracial mixing would contaminate the purity of the white race and consequently should be considered as a weak product that would not be able to produce - the term mulatta or mulatto originates from "mula," which is also the result of two incompatible species that cannot reproduce. Many authors have made use of this trope for different purposes, and Zora Neale Hurston was one of them. In her novel Their Eyes Were Watching God, Hurston creates Janie, a mulatta that a priori follows all the characteristics of this type of female character, but who actually breaks with most of them.

The tragic mulatta often referred to a light-skinned woman of mixed race who represented a middle point between white and black societies, never being completely accepted by any of them. Consequently, she is destined to suffer for different and varied reasons. This could be a general definition of this literary trope, although it is true that it was used differently by white and black writers, depending on the times and the point of view they wanted to deal with. The trope was firstly used by Lydia Maria Child, a white abolitionist who published her novels in 1840's and who created Rosalie, the protagonist of "The Quadroons." From that moment on, multiple versions are given of this character and the mulatta

\footnotetext{
${ }^{1}$ Rosalie is a near-white woman who falls in love and marries a white upper class man, despite being aware of her race. They have a daughter but Edward ultimately abandons them to marry a white woman. Edward repents but is unable to overcome political and social barriers and although he tries to protect his family, their daughter Xarifa is finally separated from her family and sold into the slave trade. She kills herself in desperation.
} 
is typically depicted as one of these three ways: the first being a woman who looked white but was actually passing for it, who has suffered little in life but loses her social status once her real identity is discovered. The second being a black woman who passed for white and falls in love with a white man but is ultimately dismissed by society when she is discovered to be the product of an interracial relationship; and the third could be a black woman who enjoys all the pleasures and benefits of white people but who is subjected to slavery once her protector dies or decides to stop helping her. ${ }^{2}$ As Eva Raimon says, "When the educated, light-skinned and sexually vulnerable female character is exposed to sexual threat due to being revealed as the offspring of a black slave and then a slave herself, she awakens the sympathies of the reader as well as functioning as a necessary plot mechanism" (5). The truth is that Hurston did not seem to be ready to conform to the standards this character implied. She stated "I am not tragically colored" ("How it Feels" 95) in her essay "How It Feels to Be Colored Me," and considered that "the world is to the strong regardless of a little pigmentation more or less" (96), considering herself "cosmic Zora" (96). That is, she purposely rejected the idea of feeling inferior because of her race and transcended the trope of tragic mulatta. Hurston also did it when she wrote, particularly in her novel Their Eyes Were Watching God, and for this reason, she created a powerful female character that used her own African American culture to find her own identity and fight against the destiny she was given due to her mixed-race condition.

Taking this into account, my contentions in this work are twofold: First to demonstrate that Hurston breaks with the traditional imagery connected to the tragic mulatta creating Janie, who overcomes all stereotypes and prejudices imposed on her due to her condition of interracial offspring and who is able to take charge of her own life and challenge all these impositions, feeling closer to her blackness and celebrating and empowering her female identity. Second, that storytelling becomes the liberating force that helps her do so. It will become the

\footnotetext{
2 Many of the novels published after Child's included these characters. Harriet Beecher Stowe's Uncle Tom's Cabin (1852), William Wells Brown's Clotel (1853), Harriet Wilson's Our Nig or Sketches from the Life of a Free Black (1859) or Frances Ellen Watkins Harper's Iola Leroy or Shadows Uplifted (1892) all presented female protagonists that follow the patron of the tragic mulatta. Beautiful mulattas who marry, fall in love or have children with white masters but who are denied a happy ending, like in Clotel and Our Nig or a mulatta as Iola Leroy, who was brought up as a white woman. She is pressed to marry a white man on the condition that she never reveals her true identity but she refuses to do it in order to marry a black man. Of course, she is never fully accepted by the black community because she is an educated woman. In the twentieth century the trope continued to be used in works by authors such as Pauline Hopkins and her novel Hagar's Daughter: Or a Story of Southern Caste Prejudice (1901-2). Here the writer uses the trope of the tragic mulatta to consider the multiple contradictions related to black women at the end of the century, as well as to deal with the idea of passing for a white person.
} 
tool that will enable her to ignore the need of passing for white and provide her with the opportunity to connect with her real identity and in this vein, feel free and happy, breaking with the tragic destiny of mulatta characters.

Janie's life can be divided into four main stages that correspond not only to the men she was related associated with but also with her growing awareness about her identity as a black woman and her decision to break with what was expected of her. Her childhood, her marriage with Logan Killicks, her relationship with Joe Starks and her love affair with Tea Cake all help her develop her personality. Her connection with storytelling will be essential to understand her evolution and to distance herself from the tragic destiny she was expected to suffer.

Janie grows up under the protection of her grandmother, Nanny. She never met her mother or father and the old woman's influence on her life will be a determining factor for her future. For the first years of her life she is completely unaware of her condition of mixed blood that she did not even know she was a "colored" girl. Living in a house on the property of Mrs. Washburn, she really believed she was like the white children she used to play with. It is not until she is six years old that she discovers that she is not white. She was happy at that time, until she got to school and children used to tease her because she used to wear better clothes than they did and because of her ribbons. At this stage of her life Janie is disconnected from her black culture, at least until white children at school started to tell her stories about her mother and her father, stories that reminded her of her origin and tried to disturb and annoy Janie. As Hurston said "I do not always feel colored... I feel more colored when I am thrown against a sharp white background" ("How it Feels" 96). Like Hurston, Janie only feels she is different when others remind her.

Nanny is presented here as a slavery sufferer who wants for her granddaughter all she could not achieve for herself and for her daughter. This implies being completely independent and unrelated to what being a black person implied at that time, enjoying the pleasures of a free life and trying to get protection from someone who can provide you with life quality, that is, trying to pass for white. This is why they moved from Mrs Washburn's backyard and why she used to remind Janie of the condition of black men and especially women.

Honey, de white man is de ruler of everything as fur as Ah been able tuh find out. Maybe it's some place way off in de ocean where de black man is in power, but we don't know nothin' but what we see. So de white man throw down de load and tell de nigger man tuh pick it up. He pick it up because he habe to, but he don't tote it. He hand it to his womenfolks. De nigger woman is de mule uh de world so fur as Ah can see. Ah been 
prayin' fuh it to be different wid you. Lawd, Lawd, Lawd! (Hurston, Eyes 14).

Nanny is resentful and conscious of racial and social inequalities, but above all, she is completely aware of sexual oppression. Most African American authors, especially African American women writers dealt with topics related to women and their strength while preserving culture and traditions. Traditionally they were categorized as mammies, concubines, conjure women and mulattas, broadly speaking. In works written by men, mammies appear idealized maternal characters and resembled the figure of the earth-mother, who had to nurture children and are always ready to help others, especially white people and their children. This is the case of works such as The Adventures of Huckleberry Finn. However, here Nanny is presented completely different. She is so aware of the differences between white and black people that she wants something better for her granddaughter. For her, black women were not only oppressed by white masters but also by their own men. Indeed, one of the reasons why the trope of the tragic mulatta became so popular in antebellum literature was that she resembled the protagonists of sentimental stories which were a popular entertainment for white women at that time. The Cult of True Womanhood was the determining ideology for middle-class women at that time and produced a true woman who was a chaste and pure heroine whose characteristics differed from those of black women and their sexuality (Carby 21). In this vein, black women were considered impure and only useful for reproduction, being excluded from womanhood and represented as sexual immoral beings. ${ }^{3}$ This is what Nanny experienced as a slave and was not ready to forget. However, unlike other mammies, Nanny had dreams. She did not want her child and her granddaughter to suffer what she suffered and never conformed to the way women were treated, she "wanted to preach a great sermon about colored women sittin'on high, but they wasn't no pulpit for me" (Hurston, Eyes 16). Her daughter was a mulatta and therefore a reminder of the master's infidelity for the white woman and of their oppression of black women. From the moment she was born, Nanny was conscious of her need to protect her from her destiny, but she could not do it. The tragic destiny of mulatta girls overtook her and she got lost, despite her mother's effort to prevent it and despite almost being born into freedom. Nanny felt Janie was another opportunity for her to develop her dreams

\footnotetext{
3 According to Barbara Welter, between the 1820's and 1860's, The Cult of True Womanhood was the stable ideology that held the Anglo-Saxon value system in place (152). The ideal of femininity was based on piety, purity, submissiveness and domesticity and circulated in magazines read by women at that time. The model continued to the nineteenth century and changed the way women perceived themselves and depicted themselves in literature (Welter 174).
}

The Grove. Working Papers on English Studies 26 (2019): 71-88. ISSN: 2386-5431. 
of seeing a really free black woman, as she would have liked to be. She said "So whilst Ah was tendin' you of nights Ah said Ah'd save de text for you Ah been waitin' a long time, Janie, but nothin' Ah been through ain't too much if you just take a stand on high ground lak Ah dreamed" (Hurston, Eyes 16). Nanny is aware that both black and white men devalue the black woman but the black woman "must nevertheless realize her potential as a woman and as a human being while avoiding victimization" (Ferguson 186). That is, Hurston concentrates on survival and search of freedom and presents a woman who struggles to achieve dignity for herself and for her offspring. As Claudia Tates states, a dominant theme was "the quest-theme - a character's personal search for a meaningful identity and for selfsustaining dignity in the world of growing isolation, meaningless and moral decay" (3). That is why she forces Janie to marry Logan Killicks when she sees her kissing a boy in the garden. For her, Janie's marriage to Killicks is her opportunity to take a step up on the social ladder. He is financially acceptable and with him Janie could have possessions. This means she will be closer to white people's position in society and that she could pass for being white, at least economically speaking.

This second stage in Janie's life turns her into a woman. From a teenager who dreams of finding a romantic love, she becomes a married woman who feels unhappy and angry because of her grandmother's pressure on getting a husband. Despite Nanny's efforts to distance Janie from the tragic destiny of mulattas, she unintentionally throws her towards it once she starts to live with Killick. Physically, Janie embodies the features that characterize mulatta. Hurston creates a character that follows this aesthetic to emphasize their resemblance, with her "coffee and cream complexion" and her long and straight black hair. However, instead of being sold to slave owners, or of being socially isolated, she becomes a slave to her husband, who treats her as a mule and who is unable to offer her the type of love she dreamed of. Initially, Killick's attentive attitude towards Janie with his rhyming words turns into that of a master who commands her to plow his fields, who buys her a mule and who treats her as a mule. He constantly reminds Janie that the appropriate place for a black woman is beyond the threshold, where she can be protected, but also where she can be treated as a slave. Killick also considers that Janie feels she was more than that because she was raised in a white kitchen surrounded by white people. He accuses her of feeling superior and of being spoiled and that is why he stops pampering her. For Janie, he is "accusing her of her mamma, her gradmama and her feelings" (Hurston, Eyes 32). Killick does not let her interact with her community, as she spends her time working on the fields. In this marriage, Janie feels miserable and captive, unable to escape from him and destined to live a life without love and passion, until she decides to run away and take control of her destiny. This happens when he meets Joe Starks The Grove. Working Papers on English Studies 26 (2019): 71-88. ISSN: 2386-5431. 
and ultimately when she discovers the real African American culture. As Sally Ann Ferguson states, when Killick buys a second-plow and reveals his plan to make Janie the dreaded mule Nanny so much hated, Janie runs off with another man, and:

Her rebellious behavior signals her early determination to defend herself against assaults on her giving and loving nature. Her rebellion is analogous to that of an actual mule later in the novel - a dumb animal that stubbornly refuses until death to submit to an even dumber man. In escaping from Logan Janie foreshadows her ability to triumph over patriarchal oppression throughout her life. (187)

When Joe Starks appears in Janie's life she uses him as an escape route that will change her routinely mundane life into something exciting and unexpected. He is presented as a way to save Janie from her tragic mulatta destiny, but again she goes straight towards it. Instead of her savior, Joe becomes Janie's captor, and storytelling became the only force that will free her. It is at this stage of her life that she finds out the importance of African American storytelling culture and her need to participate in it. As Joe becomes more and more important in Eatonville, Janie becomes more and more isolated. She starts to lose her own identity to be the Mayor's wife, a beautiful and supportive wife who did not think on her own, a status that she never fully accepted and that Joe promoted. The lovely suitor that told her about money and love became cruel and uninterested in Janie except for her role as his wife. He considered himself able to rule over anyone and anything in Eatonville and thought he was God-like, calling himself "I god" (Hurston, Eyes 35). Among the many things he thought he could control (people, money, or even the city itself) Janie was no exception. When she was asked to say a few words after Joe was appointed Mayor, he interjects and prevents her from expressing herself by saying: "Thank yuh fuh yo' compliments, but mah wife don't know nothin' 'bout no speech-makin.' Ah never married her for nothin' lak dat. She's uh woman and her place is in de home" (Hurston, Eyes 43). Joe makes his position on women and his wife's place in society clear to the town; she was a trophy doll. Indeed, it is at this point in Janie's life that Hurston emphasizes her beauty too, because for many mulattas, beauty is not a positive attribute. As Malin Pereira stated, the mulatta enters literary representation as a figure of negotiation, of "both defined female beauty and white defined literary conventions" (12). For her, "the mulatta literally embodies white aesthetics, as both artistic conventions of representation and a system of judgment of artistic value" (12). Janie's beauty attracts Joe because he views her as an object that will be useful to achieve his goals. She is young, beautiful and represents what the wife of an important man should be. This implies that she should be static and unable to think for herself. 
His obsession with getting power includes his fear of losing her and his extreme jealousy. He was jealous of anybody getting around her, so much so that he obliged Janie to tie up her hair. Indeed, this is one of Janie's most characterizing features. Her straight hair was envied by black women while black men felt attracted towards it, probably because it symbolized a white beauty model. When Joe realizes that, he decides "She was there in the store for him to look at, not those others" (Hurston, Eyes 55). By having her tie up her hair, Joe was taking control of Janie's sexuality and her interactions with other people.

Joe is often compared to Joe the Grinder as his relationship with Janie resembles that of Jody's legend. In black folklore, Jody becomes a metaphor for stagnant and fleeting adulterous relationships. Traditionally he possesses the verbal abilities and sexual prowess to seduce lonely and vulnerable women but lacks however, the money and much of everything else to keep these women after their husbands come back. Joe, like his namesake is able to seduce Janie with his words too but does it promising to turn her into his wife and that she would be envied and admired by everybody else. That is, instead of making promises of sexual good times, "he dangles before her the far horizons and newness and change that lead to the self -discovery and spiritual growth she seeks" (Ferguson 188). Because she now understands the role of money better in people's lives, she becomes more vulnerable to his offers, always thinking of her grandmother's advices, who "had always insisted that Janie could never become a lady of quality until she had a husband who treated her the same way white Washburn treated his wife" (Ferguson 188-9). However, although he gets to seduce her, he is unable to subjugate Janie completely. At this time she discovers that black people have a culture, and that she likes it. Joe had forbidden her to speak with other common people, but she finds out that she wants to be part of these people and that she enjoys their stories. On the contrary, Joe's actions within the town were all directed to the achievement of power and recognition, as well as to the control of natural processes. However, the townspeople compare his achievements to those of white owners. When he orders a ditch to be dug in front of his house to drain water, the people "murmur hotly about slavery being over" (Hurston, Eyes 75) and that they looked like servants of the big house. As Donald Marks states, "Hurston clearly considers the kind of social system Starks establishes to be as oppressive and economically unbalanced as that imposed by white society" (153). Unlike Joe, Janie does not pretend to be white or behave as such, and felt miserable when people did not fully accept her because of her social status:

Janie soon began to feel the impact of awe and envy against her sensibilities. The wife of the Mayor was not just another woman as she had supposed. She slept with authority and so she was part of it in the 
town mind. She couldn't get but so close to most of them in spirit. (Hurston, Eyes 46)

Unlike other mulatta characters and unlike Joe, who is obsessed with his power and the image that mirrors white society, she feels proud of her origins and wants to participate in them. She does not want to meet white standards or integrate into white society. As Jane Caputi stated, "the typical tragic mulatto formula centers upon a beautiful woman, whose touch of racial 'impurity' proves catastrophic, usually due to her desire for a white lover" (707). Indeed, historically the ability to pass for white was not only the condition to get citizenship but even to be considered a complete human being. At an individual level, passing for white meant that the person became white by forgetting, ignoring or denying his or her African identity. What is more, the position of the person who passed was problematic from both African American and white perspectives and for the mulatta, passing meant being considered a traitor to her race. However, for Janie the process is completely the opposite. She feels happy once she discovers the truth of her culture, and the more she participates in it, the more comfortable she is. Janie is a mulatta "who sees herself to as part of the folk" (Christian 59).

Social life in Eatonville centered around the porch, where people sat and talked about their day, as well as sharing stories and singing to have fun. "In between times, they told stories, laughed and told more stories and sung songs" (Hurston, Eyes 45). Indeed, the porch is essential to African American storytelling and Hurston provides it with an important role in the novel. It is the place where Janie feels free and close to her culture, to the people she liked to spend time with and where she did not feel like a prisoner. According to Jocelyn Hazelwood Donlon, William Faulkner's Absalom, Absalom! and Hurston's Their Eyes Were Watching God, these demonstrate how the house porch was historically set in Southern culture as an escape from the stultifying heat of summer and it became synonymous with summer socializing. It is a place where individuals can sit to watch the community go by, to welcome people and tell stories. Apart from this, according to Donlon, the porch is a transitional space between public and private where individuals can negotiate an identity within a community of shared customs, "largely through the stories they tell" (95). She says "Facilitating yet limiting access to others, the porch inextricably links community storytellers to each other, while restricting the degree of intimacy and power they can realize" (95). According to her, the novels confirm that the power of storytelling porches can be double-edged. If the individuals are able to resist the authority of the dominant community, "the overpowering constraints of the porch can virtually quash an individual's identity" (95). If it is used productively, the storytelling porches can create a space where individuals tell stories to display power in the face of an 
established social order. Janie feels empowered too. As she participates more in storytelling, she finds her voice and Joe begins to feel more threatened. She was supposed to be mute and not to make her own decisions or have an opinion, but she was not ready to accept these standards and she defended herself. Joe starts to humiliate her in public, but once again, Hurston makes her heroine win the battle of tragic destiny and Janie is able to turn the situation, responding to her husband's offenses using words and storytelling. She had been silent for too long, and had realized that her marriage had finished long ago, but one day: "Janie did what she had never done before, that is, thrust herself into the conversation" (Hurston, Eyes 75). She wanted to be heard and years after Joe mocked her about her age, for the first and last time in her life she told her husband off in front of everyone, and won:

Naw, Ah ain't no young gal no mo' but den Ah ain't no old woman neither. Ah reckon Ah looks mah age too. But Ah'm uh woman every inch of me, and Ah know it. Dat's uh whole lot more'n you kin say. You big-bellies round here and put out a lot of brah, but' tain't nothin' to it but you' big voice. Humph! Talkin' 'bout me looking' old! When you pull down you' britches you look lak de change uh life. (Hurston, Eyes 79)

Hurston provides Janie with the skill in the "dozen," a "black folk game of verbal agility in which participants attempt comically but seriously to out-insult each other. ... This folkloric device permits Janie to outperform Jody at his best skill, talking" (Ferguson 190). He is unable to control her and this makes him furious. She undercuts his link to the "Grinder" part of the myth - which is a metaphor in black folklore for a type of coital movement - implying that unlike his namesake, Jody cannot "grind" (Ferguson 190). That moment he knew he had lost:

Then Joe Starks realized all the meanings and his vanity bled like a flood. Janie had robbed him of his illusion of irresistible maleness that all men cherish, which was terrible. The thing that Saul's daughter had done to David. But Janie had done worse, she had cast down his empty armor before men and they had laughed. They would keep on laughing. ... there was nothing to do in life anymore. Ambition was useless. And the cruel deceit of Janie! (Hurston, Eyes 79-80)

Although Joe felt miserable, Janie was free to say what she thought for the first time and this would mean a new beginning in her life. When Joe became ill, she was also able to tell him about her feelings: 
You done lived wid me for twenty years and you don't know half atall. And you could have but you was so busy whorsippin' de works of you' own hands, and cuffin' folks around in their mind till you didn't see uh whole heap uh things yuh could have. (Hurston, Eyes 86)

But above all, Janie thought about herself and realized she still had a long time to live, alone and free after Joe's death. Although she was not young anymore, a "handsome woman had taken her place" (Hurston, Eyes 87). The symbol of her beauty, which had been hidden, appeared again and she "tore off the kerchief from her head and let down her plentiful hair. The weight, the length, the glory was there. She took careful stock of herself, then combed her hair and tied it back up again" (Hurston, Eyes 87). She continued with her life, untied her hair after the funeral and did what she wanted the most, to participate in porch talks: "That was the only change people saw in her. She kept the story in the same way except of evenings she sat on the porch and listened and sent Hezekiah in to wait on late custom" (Hurston, Eyes 89). Unlike other mulatta characters, Janie did not look for another suitor that would help her fit into the white world or to provide her with a wealthy lifestyle, and above all she does not want to pass for white any longer. She had been looking for love all her life and she had not found it yet, but being part of black culture gave her the chance to feel happy. However, until then, she had not had the opportunity to participate actively in storytelling, she was a mere spectator, until she met Tea Cake. This would be the beginning of a new stage in her life, maturity.

After rejecting some suitors, Janie meets Tea Cake, a completely different man from what she was accustomed to. He is not related to social order or economic profit, but unlike Killicks or Starks he is related to more mundane actions, such as gambling, fighting or storytelling. He embodies the black spirit, not the materialistic one so he does not promise Janie social status or money, rather he praises her beauty. He does not want to treat her like a mule, but teaches her to develop her abilities. His freedom allows Janie to participate more in her community than she had ever done before. However, once again Hurston creates a male character which is closely connected to an African American mythological figure. Tea Cake is often compared to the African mythological figure of Stagolee. Stagolee is categorized as a "badman," a violent man who usually breaks the law and causes trouble to those around him. There are multiple versions of his story and most of them are usually exaggerated and tragic. The most famous ballad in which he appears is the one in which he kills Billy Lyons because he had stolen his Stetson hat that "gives him trickster or shape-shifting capabilities" (Leeming and Page 172). However, his crimes do not always go unpunished, although there are multiple versions of it: 
But Stagolee does not kill with impunity. Sometimes the deputies the sheriff attempts to form into a posse are so intimidated by the famous badman they refuse to help with arrest. But almost universally the sheriff kills Stagolee or apprehends him. He is taken to court and sentenced to death. At this point the variants show the greatest difference in their treatment of Stagolee. ${ }^{4}$ (Bryant 14 )

Just after getting married he steals two hundred dollars from her and wastes them on a night of drinking and getting into trouble. He tells Janie that he just wanted to feel what it meant to be rich and promises that he will pay her back all the money he had spent gambling with the twelve dollars he still had left. Like Stagolee, he refuses to be secondary in society and "imbued with a heroic nature resistant to societal conventions, Tea Cake exhibits a freedom of spirit so assured of its own self-worth that he consequently cannot deny a similar feeling to the woman he loves" (Ferguson 192-3). However, he also behaves "bad" as Stagolee does. Indeed, he usually hits his wife in order to feel superior to her. He explains "Janie is wherever Ah wants tuh be. Dat's de kind uh wife she is and Ah love her for it. ... Ah didn't whup Janie' cause she done nothin' Ah beat her tuh show dem Turners who is boss" (Hurston, Eyes 148). With this behavior, he again resembles Stagolee who, "when compared with the traditional epic hero, does not always act in regard for his people and his woman. His exploits are often performed to exhibit his virility" (quoted in Ferguson 194).

Nevertheless, Tea Cake provides Janie with the opportunity to live a different life, closer to African American culture. She will start to live meaningfully in a community which is far from social constraints and which does not worry about emulating the structures and mechanisms of white communities. Setting the novel in Eatonville, Hurston was making a political statement. It was the first of all black towns in the country and with this the author seemed to be asking for more. It could be seen as a paradise for Afro-American people as they lived and developed in a place which was far from the racism of the white world, where they could be majors, doctors or simply themselves. However, there were some limitations too, as although they did not have to struggle against racism coming from white people, they did face gossip, sexism and jealousy, as in any other town. Eatonville was also a town opposed to the rural areas where Janie had grown up and spent the

\footnotetext{
4 The mythological figure has evolved. In antelbellum literature Stagolee was the prototype of the "bad nigger," because he was the only black man to fight the slavery system and to be unafraid of white masters. In postbellum literature, he became the hero of the black community because he faced racial discrimination with courage and strength, but was equally feared because of his inability to show constraint. In more modern tales, Stagolee turned into a lover who is able to use his gun anytime.
} 
first years of her life. It was the place where she lost her innocence and discovered her ability to deceive and where she learned to be herself. Since it was a town, it implied walls and buildings that seemed to imprison her. In fact, she felt both physically and metaphorically confined by Joe in that place and needed to leave it behind in order to feel free again. Indeed, Eatonville was totally the opposite of the rural areas where she was happy as a child. Later on, by moving the story to the Everglades, Hurston is able to offer a different version of African American people, working on fields as slaves had done previously. Hurston offers readers an insight into the life of workers and describes the way they danced, sang or played blues, told stories and met after work. This was denied to slaves, but they always found ways to socialize. Janie describes it: "All night now the jooks changed and clamored. Pianos living three lifetimes in one. Blues made and used right on the spot. Dancing, fighting, singing, crying, laughing, winning and losing love every hour" (Hurston, Eyes 131). When Janie is there and recalls her life in Eatonville, she thinks of the Everglades as the place where she could find herself and be free to tell and listen to stories:

Only here, she could listen and laugh and even talk some herself is she wanted to. She got so she could tell big stories herself from listening to the rest. Because she loved to hear it, and the men loved to hear themselves, they would 'woof' and 'booger-boo."' (Hurston, Eyes 134)

People in the Everglades did not worry about making money, owning a property or getting higher in the social scale. As Marks stated:

This is the life 'on the muck' and it is this life which Janie's passionate relationship with Tea Cake affirms. Hurston romanticizes the community on the Everglades as a kind of brotherhood that is free of the constraints and class divisions imposed by a mechanistic, capitalistic society like that of Eatonville. (155)

Her participation in the life of the community in Everglades is totally the opposite of her isolation in Eatonville, as her relationship with Joe is just the opposite of her relationship with Tea Cake. Janie does not only listen to people speak as she did in the city, but she starts to create stories and tell them, becoming a good storyteller. As Missy Dehn Kubitschek stated, "these storytelling sessions are crucial to the community unity and self-definition, since they generate and develop communal tradition. Participation in this process is also crucial for the individual's self-definition, since communal traditions define available roles" (112). Janie had a passive role in Eatonville, avoiding conflicts with her husband, but in the Everglades she is ready to participate actively in storytelling, exemplifying Hurston's “vision of the relationship between communal and 
individual definition" (Kubitschek 112). This new identification of her soul and this new understanding of her life as a participant of black society and communities separate Janie from her tragic mulatta destiny.

It is at this stage of the novel that Hurston emphasizes Janie's need to express herself and get close to African American culture, and she also does it opposing her female protagonist to others in the novel, such as Mrs. Turner, whose "disfavourite subject was Negroes" (Hurston, Eyes 208). She loves and worships all things which are white and disdains Tea Cake because he is too black, to which Janie replies "we're uh mingled people and all of us got black kinfolks as well as yaller kinfolks" (Hurston, Eyes 210). Unlike this mulatta, Janie is proud of her race and does not want to pretend to be another thing, and above all she is happy to be close to her origins. As Caputi established, the novel is

....an assertion of racial and sexual pride, and freedom and self - love for women, regardless of oppressive attitudes, regarding race, sex and age ... The characterization of Janie demolishes the stereotype of the tragic mulatta yearning to be white, while that of Mrs. Turner teaches that same type of any and all sympathy. (709)

Despite Janie's attempts to escape from the tragic destiny of mulatta characters, and despite being happier at Everglades than at any other places in the world, Hurston does not let Janie completely enjoy herself. Her relationship with Tea Cake is also related to violence and jealousy and the end had to be tragic. After being bitten by the dog and contracting rabies, Tea Cake's jealousy is exacerbated and Janie saves her life by shooting him, facing the stereotypical mulatta destiny. However, Hurston chooses for her to survive and not Tea Cake, because as Ferguson said, Hurston knows that "despite her victimization in America, the black woman is no sick machonist ... Hurston suggests that black female should stand ready to love yet defend themselves even against their own men, who occasionally place their fragile manhood above the woman's personal safety" (194). Janie is able to overcome tragedy again despite killing the love of her life. She becomes free after being helped by white women, because at the end Hurston is creating a realistic story about a black woman that may look similar to white ones. Hurston does not want her protagonist to become a simple mulatta who suffers as others do, instead she portrays a woman who was looking for love and passion all her life, who had to endure quite difficult situations on the way. When all her suitors turned difficult to deal with, she found a way to survive, because she did not want to be a victim of her destiny. 
When she returns to Eatonville after Tea Cake's death, she is again able to get over the situation, despite her loneliness as well as the gossip and the rejection of her neighbors, and she does it by becoming a storyteller. She decides to tell her own story, from the very beginning, letting people participate in it, and turning into one of the most important figures of African American literature, that of a griot or storyteller. Her tale becomes a demonstration to the town and to herself that she was victorious at the end and that, despite suffering, she could avoid the destiny of mixed-race women. As Missy Dehn Kubitschek defined, "Janie, always sufficiently knowledgeable of white culture to ensure her survival, discovers her soul only through the art of storytelling, thus intimating the artist's responsibility to, and dependence on, a larger community" (109). She could have stayed at Everglades but decides to go back to Eatonville and let people know all about her life outside that place, and she does it as a self-revelation, because after that she has to go on. She prefers to remember only good moments with Tea Cake and despite loving and losing him she has understood that their relationship has also helped her discover things about her own soul that she did not know before, and now she is able to compare: "Now, dat's how everything wus, Pheoeby, jus'lak Ah told yuh. So Ah'm back home agin and Ah'm satisfied tuh be heah. Ah done been tuh de horizon and back and now Ah kin set heah in mah house and live by comparisons" (Hurston, Eyes 191).

Janie exemplifies Hurston's desire to break with traditional stereotypes placed on African American female characters and also on mulatta characters. She does not pretend to be white but on the contrary feels proud of her race and her culture. She overcomes multiple difficulties, mostly related to the men she lived with, and finishes her life in peace and happiness. In the process she discovers her identity as a black woman and the importance of storytelling and community in the life of African American people. Hurston places Janie in difficult situations but she solves all of them. Each time she becomes freer and closer to her roots and to her own independence, celebrating her condition of African American and woman. When at the end of the novel she becomes the storyteller of her own life and experiences, the reader understands that Hurston has achieved her main purpose: creating a black protagonist who is different from other mulatta characters, providing her with a happy ending and using one of the most important elements of African American culture to get it, storytelling. 


\section{WORKS CITED}

Bryant, Jerry H. Born in a Mightily Bad Land. The Violent Man in African American Folklore and Fiction. Bloomington: Indiana UP, 2003..

Caputi, Jane. "Specifying” Fannie Hurst: Langston Hughe's Limitations of Life, Zora Neale Hurston's Their Eyes Were Watching God, and Toni Morrison's The Bluest Eyes as 'Answers' to Hurst's Imitations of Life." Black American Literature Forum 24:4 (1990): 697-716. DOI: https://doi.org/10.2307/3041797

Carby, Hazel V. Reconstructing Womanhood: The Emergence of the AfroAmerican Woman Novelist. New York: Oxford UP, 1987.

Christian, Barbara. Black Women Novelists: The Development of a Tradition, 1892-1976. Westport: Greenwood, 1980.

Donlon, Jocelyn H. "Porches: Stories: Power, Spation and Racial Intersections in Faulkner and Hurston." Journal of American Culture 19.4 (1996): 95110. DOI: https://doi.org/10.1111/j.1542-734X.1996.1904 95.x

Ferguson, Sally. "A Folkloric Men and Female Growth in Their Eyes Were Watching God." Black American Literature Forum 2.1. (1987): 185-197. DOI: https://doi.org/10.2307/2904428

Hurston, Zora N. Their Eyes Were Watching God. New York: Harper Perennial Modern Classics, 2006.

---. "How It Feels to Be Colored Me." Worlds of Difference. Inequality in The Aging Experience. Eds. Eleanor Palo and Rose Campbell. California: Pine Forge Press, 1994.

Kubitschek, Missy D. "Tuh De Horizon and Back." The Female Quest in Their Eyes Were Watching God." Black American Literature Forum 17:3 (1983):109-115. DOI: https://doi.org/10.2307/2904333

Leeming, David, and Jake Page. Myths, Legends and Folktales of America. An Anthology. Oxford: Oxford UP, 1999.

Marks, Donald R. "Sex, Violence, and Organic Consciousness in Zora Neale Hurston's Their Eyes Were Watching God." Black American Literature Forum 19:4 (1985): 152-157. DOI: https://doi.org/10.2307/2904277

Pereira, Malin. Embodying Beauty: Twentieth Century American Women Writer's Aesthetics. New York: Garland Publishing Inc., 2000.

Raimon, Eva A. The Tragic Mulatta Revisited: Race and Nationalism in Nineteenth Century Antislavery Fiction. New Brunswick: Rutgers UP, 2004. 
Tate, Claudia. Domestic Allegories of Political Desire: The Black Heroine's Text at the Turn of the Century. New York: Oxford UP, 1992.

Welter, Barbara. "The Cult of True Womanhood: 1820-1860." American Quarterly 18 (1966): 151-174. DOI: https://doi.org/10.2307/2711179 
